\title{
Nitrogen fertiliser use in early lambing systems
}

\author{
G.W. SHEATH, C.J. BOOM and R.W. WEBBY \\ Whatawhata Research Centre, MAF Technology, Private Bag 3089, Hamilton
}

\begin{abstract}
Nitrogen fertiliser was applied in June 1990 to early-August lambing systems and production was compared with traditional September lambing. Nitrogen (30 kg N/ha) increased pasture growth rates by $3-4 \mathrm{~kg} \mathrm{DM} / \mathrm{ha} /$ day and increased production by $210 \mathrm{~kg}$ DM/ha during July-September inclusive, Nitrogen responses were greatest in southfacing paddocks; least on easy contoured paddocks; and did not differ between "resident" pastures and "improved" pastures that had been oversown with new pasture cultivars 5 years before. Compared with traditional September lambing, early-August lambing (plus N) resulted in $20 \%$ fewer lambs at weaning; $2.4 \mathrm{~kg}$ heavier lamb weaning weights; similar ewe weaning weights; and similar bull live weights in January. While $\mathrm{N}$ applications to earlier lambing systems reduced the differences in ewe and bull weights previously recorded between the lambing date treatments, it wasnotaprofitablestrategy. Assessmentofpasture response to $\mathrm{N}$ (30 kg N/ha) was repeated in 1991. Nitrogen increased production by $260 \mathrm{~kg}$ DM/ha and responses were similar for all paddock and pasture types.
\end{abstract}

Keywords nitrogen fertiliser, early lambing, hill country

\section{Introduction}

Earlier lambing is an option available to farmers for producing heavier lambs. For 3 years the production of early versus late lambing systems were compared in hill country farmlets at Whatawhata (Sheath et al. 1990). In summary, early August lambing was less profitable than traditional September lambing.

Nitrogen $(\mathrm{N})$ application in June was seen as a strategy to counteract the greater feed deficits created by earlier lambing. In dairying, earlier calving plus $\mathrm{N}$ has increased cow production and condition (Roberts \& Thomson 1989); and in hill country large pasture and animal responses have been reported (Lambert \&
Clark 1986). The objective of the experiment reported in this paper was to use $\mathrm{N}$ fertiliser in early lambing systems to improve July-August pasture growth and to eliminate poorer ewe and bull weights that had previously been experienced relative to September lambing. The response of pasture and animal production to $\mathrm{N}$ fertiliser was measured in 1990 and a repeat assessment of pasture response was made in 1991.

\section{Experimental detail}

The trial consisted of a $2 \times 2$ factorial with 3 replicates (as described by Sheath et al. 1990). with treatments comparing pasture improvement and lambing date. During the third week of June 1990, all paddocks in each of the early lambing farmlets received $30 \mathrm{~kg} \mathrm{~N} /$ ha as urea.

\section{Stock policies}

The 12 self-contained farmlets (5-6 ha) carried Romney $x$ Coopworth ewes $(9.2 / \mathrm{ha})$ and Friesian bulls $(0.9 / \mathrm{ha})$. Six early-lambing (EL) farmlets had a mean lambing of the second week in August while the six latelambing (LL) farmlets had a mean lambing of the second week in September.

Lambs were all weaned on 15 November and the heaviest were retained on the farmlets at 6/ha until disposal on 16 January. Lamb weaning dollar values were calculated on potential prices at the time of weaning whilesalevalueswerethoseactuallyreceived.

Bulls were placed on farmlets in November as 3month weaners, and were disposed of at 18-20 months of age.

\section{Farmlet structure}

The farmlet land area consisted of $2 / 3$ steep land $\left(>15^{\circ}\right.$ average slope) and $1 / 3$ easy land $\left(<15^{\circ}\right)$. Within the six improved farmlets the steep land had been oversown 4 years previously with 'Ellett' ryegrass, 'Grasslands Wana' cocksfoot, 'Grasslands Tahora' and 'Prop' white clovers and 'Mount Barker' and 'Tallarook sub-clovers. The improved farmlet easy land had been 
oversown with 'Grasslands Marsden' ryegrass 1 year previously. Pasture composition was assessed during September 1990 using a $5 \mathrm{~mm}$ ring presence/absence technique (Table 1).

Table 1 Species composition of paddocks in early lamb farmlets in September, 1990. (percentage frequency with $5.0 \mathrm{~mm}$ sampling ring).

\begin{tabular}{lcccc}
\hline & & \multicolumn{3}{c}{ Paddock type } \\
& & $\begin{array}{c}\text { Easy } \\
\text { contour }\end{array}$ & $\begin{array}{c}\text { North } \\
\text { aspect }\end{array}$ & $\begin{array}{c}\text { South } \\
\text { aspect }\end{array}$ \\
\hline \multirow{2}{*}{ Ryegrass } & Resident & 77 & 55 & 45 \\
& Improved & 77 & 50 & 52 \\
Browntop & Resident & 25 & 31 & 33 \\
& Improved & 8 & 26 & 22 \\
Poa spp. & Resident & 29 & 14 & 9 \\
Other grasses & Improved & 38 & 18 & 18 \\
& Resident & 12 & 29 & 34 \\
Cocksfoot & Improved & 4 & 20 & 22 \\
\multirow{2}{*}{ White clover } & Resident & 0 & 3 & 1 \\
& Improved & 0 & 10 & 15 \\
& Resident & 32 & 18 & 19 \\
& Improved & 38 & 18 & 27 \\
\hline
\end{tabular}

\section{Pasture measurements}

Nitrogen response was determined within the earlylambing farmlets. In each of these 6 farmlets, 3 paddocks were selected to measure the response to $\mathrm{N}$ application (1 easy, 1 north facing steep and 1 south facing steep). Four pairs of $2 \mathrm{~m} \times 2 \mathrm{~m}$ plots were placed in each paddock. Within each pair $\mathrm{N}$ was applied to one plot and omitted from the other. Cages were placed on these plots and pasture growth was measured for 3 time periods $(28 / 6-9 / 8 ; 9 / 8-6 / 9 ; 6 / 9-1 / 10)$ using a calibrated capacitance probe. Where cage placement did not coincide with grazings of these indicator paddocks, measurement areas were trimmed to residuals of 700, 900 and $1050 \mathrm{~kg} \mathrm{DM} / \mathrm{ha}$ for the 3 regrowth periods respectively. Except for period 1 these levels approximated the actual grazing residuals that occurred in the total farmlets.

Average pasture cover was determined for both early- and late-lambing farmlets in May, August and November. Pasturemass inallpaddocks wasestimated using a calibrated visual assessment technique.

Assessment of pasture response to $\mathrm{N}$ was repeated in 1991 . In the third week of June, the $\mathrm{N}$ treatment was rerandomised and applied (30 kg N/ha as urea) to one plot and omitted from the other. Pasture growth was measured as described above for the periods $27 / 6-8 / 8$ and $3 / 8-5 / 9$.

\section{Climate}

Climaticdatafor winter-spring of 1990 and 1991, and long term averages, are given in Table 2.

\section{Results and discussion}

\section{Animal production}

In previous years of this experiment (Sheath et $\boldsymbol{a l}$. 1990) lambing during early August, rather than early September, resulted in:

* $\quad 15-30 \%$ fewer lambs born per ewe lambing * $530 \%$ fewer lambs weaned per ewe mated * 2.0-2.5 kg heavier average lamb weaning weight * $2.0-4.0 \mathrm{~kg}$ lighter ewe weaning weight

* 10-20 kg lighter bulls at slaughter

In this 1990 experiment, relative lambing performance was already established by the time urea $(30 \mathrm{~kg} \mathrm{~N} / \mathrm{ha})$ was appliedto EL farmlets. As inprevious years, lambing performance was $20 \%$ lower for EL farmlets (Table 3). Ovulation rates of cross-bred ewes can be expected to be

Table 2 Climate data for Whatawhata Research Centre (N.Z. Met. Service site C75801). Data in parenthesis are 1952-1990 averages.

\begin{tabular}{|c|c|c|c|c|c|c|c|}
\hline & & May & Jun & Jul & Aug & Sep & Oct \\
\hline Rainfall (mm) & $\begin{array}{l}1990 \\
1991\end{array}$ & $\begin{array}{r}40 \\
(149)\end{array}$ & $\begin{array}{r}150 \\
147 \\
(158)\end{array}$ & $\begin{array}{c}195 \\
251 \\
(166)\end{array}$ & $\begin{array}{r}319 \\
247 \\
(157)\end{array}$ & $\begin{array}{r}110 \\
(130)\end{array}$ & $\begin{array}{r}160 \\
(140)\end{array}$ \\
\hline Air temperature $\left({ }^{\circ} \mathrm{C}\right)$ & $\begin{array}{l}1990 \\
1991\end{array}$ & $\begin{array}{c}12.0 \\
11.1 \\
(11.8)\end{array}$ & $\begin{array}{c}8.7 \\
9.5 \\
(9.7)\end{array}$ & $\begin{array}{r}10.0 \\
7.9 \\
(\mathbf{8 . 9})\end{array}$ & $\begin{array}{l}10.4 \\
11.0 \\
(9.9)\end{array}$ & $\begin{array}{r}9.8 \\
(11.5)\end{array}$ & $\begin{array}{c}13.8 \\
\cdot \\
(13.1)\end{array}$ \\
\hline Number days grass minimum $<-1.0^{\circ} \mathrm{C}$ & $\begin{array}{l}1990 \\
1991\end{array}$ & $\begin{array}{r}3 \\
(5)\end{array}$ & $\begin{array}{l}11 \\
(9)\end{array}$ & $\begin{array}{r}4 \\
17 \\
(11)\end{array}$ & $\begin{array}{r}5 \\
2 \\
(8)\end{array}$ & $\begin{array}{l}14 \\
\text { (4) }\end{array}$ & $\begin{array}{r}3 \\
(2)\end{array}$ \\
\hline $10 \mathrm{~cm}$ soil temperature $\left({ }^{\circ} \mathrm{C}\right)$ & $\begin{array}{l}1990 \\
1991\end{array}$ & $\begin{array}{r}11.1 \\
9.9 \\
(11.2)\end{array}$ & $\begin{array}{c}8.4 \\
8.2 \\
(9.1)\end{array}$ & $\begin{array}{c}8.5 \\
6.4 \\
(7.8)\end{array}$ & $\begin{array}{c}9.1 \\
9.4 \\
(8.8)\end{array}$ & $\begin{array}{c}9.0 \\
\dot{-} \\
(10.7)\end{array}$ & $\begin{array}{c}13.6 \\
\cdot \\
(13.2)\end{array}$ \\
\hline
\end{tabular}


Table 3 Animal performance for early and late lambing famlets.

\begin{tabular}{|c|c|c|c|c|}
\hline & $\begin{array}{c}\text { Early lamb } \\
\text { plus Nitrogen }\end{array}$ & Late lamb & $\mathrm{SED}^{\mathrm{a}}$ & Significance ${ }^{b}$ \\
\hline \multicolumn{5}{|l|}{ Lambs } \\
\hline Lambs born/ewe lambing & 1.39 & 1.55 & 0.06 & . \\
\hline Lambs weaned/ewe mated & 0.95 & 1.17 & 0.07 & . \\
\hline Lamb weaning weight(kg) & 20.2 & 17.6 & 0.5 & .. \\
\hline$\$$ sale value/ha & 156 & 161 & 10 & N S \\
\hline \multicolumn{5}{|l|}{ Ewe Livewelghts $(\mathrm{kg})$} \\
\hline $3 / 5 / 90$ & 52.3 & 53.1 & 0.7 & N S \\
\hline $16 / 11 / 90$ & 45.5 & 45.9 & 0.3 & N S \\
\hline $15 / 1 / 91$ & 50.6 & 51.1 & 0.7 & N S \\
\hline \multicolumn{5}{|l|}{ Bull Liveweights(kg) } \\
\hline $17 / 5 / 90$ & 223 & 225 & 6.4 & N S \\
\hline $1 / 8 / 90$ & 280 & 286 & 6.9 & N S \\
\hline $29 / 11 / 90$ & 417 & 426 & 11.7 & N S \\
\hline $\begin{array}{l}9 / 1 / 91 \\
\$\end{array}$ & $\begin{array}{l}455 \\
461\end{array}$ & $\begin{array}{l}458 \\
496\end{array}$ & 9.4 & N S \\
\hline
\end{tabular}

a standard error of the difference

significance level : 'P<0.05; • $P<0.01$

lower for February/March compared with April matings. Average lamb weaning weights in EL farmlets were again $2.4 \mathrm{~kg}$ heavier.This wouldhavebeenaconsequence of greater age and less twinning. Ewe weaning weights were similar for both lambing date treatments. The 2-4 kgliveweightdisadvantagethatwasrecordedinprevious years disappeared with the application of $\mathrm{N}$ to $\mathrm{EL}$ farmlets. Similarly, differences in bull liveweights at slaughter were not recorded in this experiment.

These results indicate that the application of $30 \mathrm{~kg}$ $\mathrm{N} / \mathrm{ha}$ was able to counter-balance extra feed deficits created by lambing 1 month earlier; and was able to negate any animal liveweight disadvantages. They reinforce the importance of early lactation feeding in influencing ewe performance (McCall et al. 1986). Note, however, that $\mathrm{N}$ application wouldnotbe expected to counter the lower lambing levels that result from earlier mating.

\section{Farmlet response to nitrogen}

Application of $\mathrm{N}$ to EL farmlets was seen as a means of overcoming greater feed deficits, and of avoiding very low pasture covers during early lactation that would limit actual regrowth. It was recognised that the response of current pasture growth during AugustSeptember would be inadequate to achieve these objectives; therefore $\mathrm{N}$ was applied in late June. It was expected that a strict winter rotation would accumulate extra winter feed and transfer it into early lactation.

The overall pasture response to $\mathrm{N}$ in 1990 (Table 4) was $7 \mathrm{~kg} \mathrm{DM} / \mathrm{kg} \mathrm{N}$. This response was very similar to the $9 \mathrm{~kg} \mathrm{DM} / \mathrm{kg} \mathrm{N}$ measured in the following year. While these values are at the lower end of the response range reported by O'Connor (1982). they are of a similar magnitude to those reported by Ledgard et al. (1983) at the same location. The transfer of extra feed into August was achieved. Compared with previous years, EL farmlets had greater pasture cover than LL farmlets (Table 5). However, absolute cover levels of both treatments were still low, and once ewes were set stocked in EL farmlets, pasture covers declined to $700-750 \mathrm{~kg} \mathrm{DM} / \mathrm{ha}$. In 1990, July was warmer than normal, August was very much wetter and September much colder than the long term mean (Table 2). These conditions would have provided a good test of the impact of $\mathrm{N}$ response and feed transfer.

Filling feed gaps and maintaining pasture cover at levels that allow the full expression of potential pasture growth, both seem essential for any system to fully benefit from $\mathrm{N}$ applications. The indirect benefits of $\mathrm{N}$ that occur via cover maintenance must play a major part in high response values $(25-30 \mathrm{~kg} D M / \mathrm{kg} \mathrm{N})$ recorded in other self-contained farmlets (Lambert \& Clark 1986; Hoglund \& Pennell 1989). In this experiment extra feed was transferred into early lactation, but once ewes were set-stocked and intake was unrestricted, pasture cover could not bemaintained. The approach of applying $\mathrm{N}$ across the total farm area to overcome early lactation feed deficits seems wrong. More effective use of $\mathrm{N}$ may have occurred if it had been applied to paddocks designated for cattle and a greater proportion of the farm area then allocated to ewes. Pasture cover would be bettermaintained by this 
Table 4 Pasture growth rates ( $\mathrm{kg} \mathrm{DM} / \mathrm{ha} / \mathrm{day})$ as influenced by nitrogen, pasture improvement and paddock type in early lambing farmlets.

\begin{tabular}{|c|c|c|c|c|c|c|}
\hline & $\begin{array}{c}\text { All } \\
\text { paddocks }\end{array}$ & $\begin{array}{l}\text { Resident } \\
\text { paddocks }\end{array}$ & $\begin{array}{l}\text { Improved } \\
\text { paddocks }\end{array}$ & $\begin{array}{c}\text { Easy } \\
\text { contour }\end{array}$ & $\begin{array}{l}\text { North } \\
\text { aspect }\end{array}$ & $\begin{array}{l}\text { South } \\
\text { aspect }\end{array}$ \\
\hline \multicolumn{7}{|l|}{1990} \\
\hline \multicolumn{7}{|c|}{ Period 1 (28 June . 9 August) } \\
\hline $\begin{array}{l}\text { Nitrogen } \\
\text { No nitrogen } \\
\text { SED } \\
\text { Significance }\end{array}$ & $\begin{array}{c}26.1 \\
22.3 \\
0.8 \\
* * 4\end{array}$ & $\begin{array}{l}24.8 \\
21.9\end{array}$ & $\begin{array}{l}27.3 \\
22.6\end{array}$ & $\begin{array}{l}28.2 \\
25.2\end{array}$ & $\begin{array}{l}24.1 \\
22.3 \\
2.7 \\
. a\end{array}$ & $\begin{array}{l}25.9 \\
19.2\end{array}$ \\
\hline \multicolumn{7}{|c|}{ Period 2 (9 August . 6 September) } \\
\hline $\begin{array}{l}\text { Nitrogen } \\
\text { No nitrogen } \\
\text { SED } \\
\text { Significance }\end{array}$ & $\begin{array}{r}18.6 \\
15.6 \\
1.0\end{array}$ & \multicolumn{2}{|c|}{$\begin{array}{l}2.1 \\
\text { N S }\end{array}$} & \multicolumn{3}{|c|}{2.1} \\
\hline \multicolumn{7}{|c|}{ Period 3 (6 September $\cdot 1$ October) } \\
\hline $\begin{array}{l}\text { Nitrogen } \\
\text { No nitrogen } \\
\text { SED } \\
\text { Significance }\end{array}$ & $\begin{array}{l}37.0 \\
39.1 \\
1.9 \\
\text { N S }\end{array}$ & \multicolumn{2}{|c|}{6.1} & $\begin{array}{l}40.6 \\
48.9\end{array}$ & $\begin{array}{r}39.9 \\
36.6 \\
4.7 \\
\text { N S }\end{array}$ & $\begin{array}{l}30.5 \\
31.9\end{array}$ \\
\hline \multicolumn{7}{|l|}{1991} \\
\hline \multicolumn{7}{|c|}{ Period 1 (27 June . 8 August) } \\
\hline $\begin{array}{l}\text { Nitrogen } \\
\text { No nitrogen } \\
\text { SED } \\
\text { Significance }\end{array}$ & $\begin{array}{r}21.9 \\
16.5 \\
0.8 \\
*+4\end{array}$ & \multicolumn{2}{|c|}{$\begin{array}{l}3.2 \\
\text { N S }\end{array}$} & $\begin{array}{l}26.1 \\
20.6\end{array}$ & $\begin{array}{l}22.1 \\
16.2 \\
2.7 \\
\text { N S }\end{array}$ & $\begin{array}{l}17.6 \\
12.8\end{array}$ \\
\hline \multicolumn{7}{|c|}{ Period 2 (8 August . 5 September) } \\
\hline $\begin{array}{l}\text { Nitrogen } \\
\text { No nitrogen } \\
\text { SED } \\
\text { Significance }\end{array}$ & $\begin{array}{r}30.7 \\
28.8 \\
0.8 \\
\ldots\end{array}$ & $\begin{array}{l}30.0 \\
28.0\end{array}$ & $\begin{array}{l}31.3 \\
29.6\end{array}$ & $\begin{array}{l}43.2 \\
42.6\end{array}$ & $\begin{array}{c}26.7 \\
23.1 \\
2.3 \\
\mathrm{~N} \mathrm{~S}\end{array}$ & $\begin{array}{l}22.2 \\
20.6\end{array}$ \\
\hline
\end{tabular}

statistical significance of Interactions

Table 5 Average pasture cover ( $\mathrm{kg} \mathrm{DM} / \mathrm{ha}$ ) for early and late lambing farmlets.

\begin{tabular}{llccc}
\hline & & May & August & November \\
\hline \multirow{2}{*}{1987} & Early lamb & 1320 & 841 & 980 \\
& Late lamb & 1310 & 910 & 1250 \\
& Significance & N S & $*$ &.$\cdot$ \\
1988 & Early lamb & 1840 & 740 & 1420 \\
& Late lamb & 1940 & 980 & 1490 \\
& Significance & N S & $\cdot$ & N S \\
& Early Lamb & 1820 & 890 & 2090 \\
& Late lamb & 1840 & 920 & 2170 \\
& Significance & N S & N S & N S \\
& Early lamb + N & 1050 & 920 & 1520 \\
& Late lamb & 1030 & 800 & 1480 \\
& Significance & N S & $\cdot$ & $*$ \\
\hline
\end{tabular}

approach. Use of low $\mathbf{N}$ rates across large areas of the farm seems more sensible for autumn applications where extra feed is used within winter rotations to improve stock carrying capacity.
Land class response to nitrogen

While $\mathbf{N}$ was applied to all paddocks in each EL farmlet, pasture growth responses differed between paddock type in 1990 (Table 4). Steep south-facing paddocks were the more responsive during the first two growth periods; and easy contoured paddocks experienced growth rate depressions during the third growth period. In 1991 , responses were similar for the 3 paddock types.

It is generally considered that greater responses to $\mathbf{N}$ fertiliser will occur on easier contoured ryegrass pastures and or warmer aspects (Ledgard et al. 1983). This did not ocaur in these experiments. It is possible that there is an optimum temperature for maximising $\mathrm{N}$ response that takes into account the relative effect of temperature on soil $\mathbf{N}$ supply and plant growth itself. During the warmer-than-normal July 1990, pasture growth may have been most restricted by soil $\mathrm{N}$ supply and this restriction would have been greatest on colder 
southerly paddocks. Hence $\mathrm{N}$ response was greater in these paddocks. However, where lower-than-normal temperatures are experienced, as in July 1991. the direct effect of cold on pasture growth itself and the ability of pasture to respond to $\mathrm{N}$ will be most severely felt in southerly paddocks.

The context within which these response patterns were measured must be remembered. Pastures in these farmlets were very well developed (Table 1) and winter temperatures were not low by $\mathrm{New}$ Zealand standards (Table 2). The general rule that easier contouredryegrass pastures and/or warmer aspects are more responsive to $\mathrm{N}$ fertiliser is not challenged. Nevertheless, on well developed hill land in the warmer areas of the North Island it can be expected that southerly paddocks will be as responsive to $\mathrm{N}$ fertiliser as any other paddock type.

\section{Pasture type response to nitrogen}

The introduction of new pasture cultivars into existing hill pastures was considered as a means of improving winter-early spring feed supply, especially for EL farmlets. To date, no animal production advantages have been achieved through these introductions (Webby et al. 1990). In this 1990 experiment there was an opportunity to assess whether pasture development affected the level of $\mathrm{N}$ response. While there was a tendency for greater $\mathrm{N}$ responses in improved pastures, any development $\times$ Ninteractions were not statistically significant. The same result also occurred in 1991. However, the composition of the improved and the well managed resident pastures differed mainly in cocksfoot and low fertility grasses (see Table 1).

\section{Nitrogen response measurements}

Estimates of dry matter response to $\mathrm{N}$ were determined within EL farmlets. As indicated by low error estimates, the approach of paired plots within variable hill paddocks, and the use of a capacitance probe to indirectly measure small changes in dry matter, was valuable. Any concern with the $\mathrm{N}$ response data centres on the overestimation of absolute pasture growth during period 1 . This was a consequence of trim residuals being $200 \mathrm{~kg} \mathrm{DM} / \mathrm{ha}$ higher than actual postgraze levels. Post-pre paddock estimates were $8 \mathrm{~kg}$ $\mathrm{DM} / \mathrm{ha} /$ day lower than the $\mathrm{N}$ trial estimates.

\section{Economic outcome}

While early lambing plus $\mathrm{N}$ produced heavier lambs and achieved similar ewe and bull weights. the per hectare returns were still $\$ 20$ less than for LL farmlets
(Table 3). Fewer lambs for sale in the EL farmlets was the major disadvantage. There was also the additional cost of $\mathrm{N}$. At current prices that ranged from $\$ 1.20 / \mathrm{kg}$ $\mathrm{N}$ (Bulk; fixed wing) to $\$ 1 \mathrm{SO} / \mathrm{kg} \mathrm{N}$ (bagged; helicopter), the use of $\mathrm{N}$ to help create more profitable early lambing systems cannot be recommended. With the stock policy employed in the early lambing systems, $\mathrm{N}$ responses would have had to be $1418 \mathrm{~kg} \mathrm{DM} / \mathrm{kg} N$ to break even with increased costs, and then this response would have needed to be predominantly expressed as increased bull weights. Reported responses to the use of $\mathrm{N}$ are highly variable, but such high response requirements cannot reliably be expected in hill lands.

If $\mathrm{N}$ is to be considered, then its more likely use is to improve winter carrying capacity, so that ultimately, feed can be used more effectively during periods of abundance. Aconsensus view is required on the means of achieving full benefits of $\mathrm{N}$ application in a sheep and beef system.

\section{Conclusion}

Early lambing strategies increase feed deficits in early lactation and lead topoorerewe and cattle performance. Application of $\mathrm{N}$ in late winter can negate these disadvantages, but it is not a strategy that proved economically acceptable in this experiment.

\section{ACKNOWLEDGEMENTS}

Thanks to B. Carlson for technical work and B. Dow for statistical analyses.

\section{REFERENCES}

Hoglund, J.H.; Pennell, C.G.L. 1989. A utumnnitrogen fertiliser in a dryland sheep system. Proceedings of the NZ Grassland Association 50: 135-138.

Lambert, M.G.; Clark, D.A. 1986. Effects of lateautumn nitrogen application on hill country pastures and sheep production. Proceedings of the NZ Grassland Association 47: 21 I-215.

Ledgard, S.F.; Brier. G.J.; Gillingham. A.G.; Sheath, G.W. 1983. Influence of some soil and pasture components on the growth of hill country pastures II. Response to nitrogen fertiliser. NZ journal of experimental agriculture 11: 25 I-256.

McCall, D.G.; Smeaton. D.C.; Wadams, T.K. 1986. Lambing date, ewe live weight and pasture mass effects on ewe and lamb performance during lactation. Proceedings of the NZ Society of Animal Production 46: 129-I 32.

O'Connor, M.B. 1982. Nitrogen fertilisers for the production of out-of-season grass. In Nitrogen 
Fertilisers in New Zealand Agriculture (P.B. Lynch ed.) pp. 65-76. NZ Institute of Agricultural Science.

Roberts,A.H.C.;Thomson,N.A. 1989. Use of nitrogen fertiliser for intensive dairy production. InNitrogen in New Zealand Agriculture and Horticulture (Ed. R.E. White \& L.D. Currie). Massey University.

Sheath, G.W.; Webby, R.W.; Pengelly, W.J.; Boom C.J. 1990. Finishing lambs in steep hill country. Proceedings of the NZ Grassland Association 51: 181-186.

Webby R.W.; Sheath, G.W.; Boom C.J., 1990. Performance of new pasture cultivars in a hill country finishing system. Proceedings of the $\mathrm{NZ}$ Grassland Association 51: 151-156. 